\title{
Effect of Rhizobium and Intercropping Systems on Soil Nutrients and Biological Nitrogen Fixation as Influenced by Legumes (Phaseolus vulgaris and Dolichos lablab)
}

\author{
Prosper I. Massawe ${ }^{\mathrm{I} *}$, Kelvin M. Mtei ${ }^{2}$, Linus K. Munishi ${ }^{1}$ and Patrick A. Ndakidemi ${ }^{1}$ \\ ${ }^{1}$ Department of Sustainable Agriculture and Biodiversity Management, The Nelson Mandela \\ African Institution of Science and Technology, P.O. Box 447, Arusha, Tanzania \\ ${ }^{2}$ Department of Water and Environmental Sciences, The Nelson Mandela African Institution of \\ Science and Technology, P.O. Box 447, Arusha, Tanzania \\ *Corresponding author
}

\section{Keywords}

Biological nitrogen fixation, Intercropping systems, Legumes, Soil nutrients, Rhizobium.

\section{Article Info}

Accepted:

12 September 2016 Available Online: 10 October 2016

\section{A B S T R A C T}

The study was conducted to assess the effect of Rhizobium inoculation and intercropping systems on soil nutrients improvement and biological nitrogen fixation as influenced by two legumes (Phaseolus vulgaris and Dolichos lablab). To achieve this aim, the field experiments were conducted at Selian Agricultural Research Institute (SARI) for two seasons. The fertility status of the soils and their suitability for cereal/ legumes production at the experimental site was evaluated based on technical indicators of soil fertility. From the soil analytical results, the major soil fertility limitations included low soil organic matter, low total nitrogen and medium available phosphorus for season 1 hence the soils were categorized as of low fertility status and moderately suitable for cereal/ legumes production. This was opposite in season 2 due to legumes biological nitrogen fixation and incorporation of legumes crop residues into the soil as the results of the first season harvest. A randomized complete block design was used in a 3-factorial arrangement with two levels of Rhizobium (with and without rhizobia), 2 legumes (P. vulgaris and D. lablab) and 5 cropping systems. The results showed that Rhizobium inoculation was significantly $(\mathrm{P} \leq 0.001)$ on nodules number per plant; nodules weight $(\mathrm{g})$ and biological nitrogen fixation $\left(\mathrm{kg} \mathrm{N} \mathrm{ha}^{-1}\right)$ in season 1 and 2 . Based on these findings, it is thus recommended that, Rhizobium inoculation is the most profitable biofertilizer for soil fertility restoration.

\section{Introduction}

The majority of farmers in sub-Saharan Africa (SSA) lack financial resources to purchase sufficient amount of mineral fertilizers to replace soil nutrients removed through harvested crop products (Jama et $a l ., 2000)$. This is because price of inorganic fertilizer in SSA is several times higher than world food prices (CIAT-TSBF, 2004). In this case, poor soil fertility has emerged as one of the greatest biophysical constraint to increasing agricultural productivity hence threatening food security in SSA region 
(Mugwe et al., 2009). Of all the plant nutrients, nitrogen $(\mathrm{N})$ is the most commonly deficient in soils, contributing to reduced agricultural yields throughout the SSA (Myers, 1988).

In Tanzania soil fertility assessments showed that $77 \%$ of agricultural soils have very low $(0.01 \%)$ to low $(0.15 \%) \mathrm{N}$ content (MAFC, 2013). $\mathrm{N}$ has been gradually depleted from the soils and now poses serious threats to successful production of food and requires the use of $\mathrm{N}$ fertilizer (Kong et al., 2008). This problem can be alleviated by the use of nitrogen fertilizers which on the other hand increases the cost of production to farmers and adversely affect the environment (Gadalla et al., 2010; Gibson et al., 2013). The sustainable way to solve the problem of nitrogen deficiency is to use the environmental friendly biological nitrogen fixation technology in cropping systems (Gibson et al., 2013).

The potential uses of biofertilizers in agriculture play an important role of providing an economically viable level for achieving the ultimate goal to enhance productivity. In a study of Rhizobial cross inoculation groups of Faidherbia albida and Acacia nilotica, Acacia senegal, A. tortilis, A. seyal and $A$. melifera, it was found that the frequency of nodulation and total nitrogen content were maximized when each individual plant species was inoculated with its own isolate of Rhizobium (Gadalla et al., 2010).

The nitrogen derived from the air was calculated to be about $79-80 \%$ indicating that most legumes fixed more than $70 \%$ of its $\mathrm{N}$ need from the air (Ahmed et al., 2005). Studies conducted in Australia showed that, legume produced an average of $225 \mathrm{~kg} \mathrm{~N}$ ha-1, and replaced over $60 \%$ of the $\mathrm{N}$ fertilizer requirement for optimum cotton production (Zablotowicz et al., 2011). The contribution of legume crops on cereal crop yields indicated an increase in yields of crops planted after harvesting of legumes are often equivalent to those expected from application of $30-80 \mathrm{~kg}$ of fertilizer- $\mathrm{N} \mathrm{ha}^{-1}$ (Peoples et al., 2009). Legumes, such as common beans (Phaseolus vulgaris L.) and dolichos lablab (D. lablab L.) have the ability to form a symbiotic relationship with soil bacteria capable of trapping nitrogen gas $\left(\mathrm{N}_{2}\right)$ from the atmosphere and converting it into ammonia, which can be used by the plant for growth, development and seed production (Lodwig et al., 2003; Kabahuma, 2013). Atmospheric nitrogen is converted to ammonia by the nitrogenase enzyme in a process known as biological nitrogen fixation (BNF) (Postgate, 1998). The Biological nitrogen fixation (BNF) process offers an economically attractive and ecologically sound means of reducing external nitrogen input and improving the quality and quantity of internal resources (Rahman, 2013).

The capacity of legumes to fix atmospheric nitrogen gives them an advantage over nonleguminous crops when grown on soils low in nitrogen (Postgate, 1998). Dolichos lablab and common bean legumes are capable of producing large quantities of biomass and fix substantial quantities of $\mathrm{N}$ for subsequent crops but the benefits they bring to the farming systems in Tanzania are not well documented. Further, Dolichos lablab and Phaseolus vulgaris are practiced as mono and intercrop without Rhizobium inoculation. Therefore, by realizing the benefits of the legume crop-Rhizobium symbiosis, it is necessary to quantify the amount of nitrogen fixed by the Rhizobium inoculated Dolichos lablab and common bean in maize/legume intercropping systems and its effect into the soil for subsequent crops. 


\section{Materials and Methods}

\section{Description of the research experimental site}

Two field experiments were conducted at SARI farm in northern part of Tanzania (April 2015 to September 2015 and October 2015 to February 2016). SARI lies at Latitude $3^{\circ} 21^{\prime} 50.08^{\prime \prime}$ and Longitude $36^{\circ} 38^{\prime} 06.29^{\prime \prime} \mathrm{E}$ at an elevation of 1390masl with mean annual rainfall of $870 \mathrm{~mm}$. The mean maximum temperature ranges from $22^{\circ} \mathrm{C}$ to $28^{\circ} \mathrm{C}$ whiles the mean minimum temperature ranges from $12^{\circ} \mathrm{C}$ to $15^{\circ} \mathrm{C}$ respectively.

\section{Soil samples collection and analysis}

Following land preparation, but prior to planting, two soil samples at $0-20 \mathrm{~cm}$ depth were collected from the experimental site in a zigzag mode, pooled, and sub-samples taken for physical and chemical analysis. The soil properties determined included soil $\mathrm{pH}$, electrical conductivity (EC), organic carbon (OC), cation exchangeable capacity (CEC), total nitrogen (TN), available phosphorous, exchangeable bases, plant available zinc, copper, manganese and iron and particle size distribution.

The soil $\mathrm{pH}$ was measured electrometrically in 1:2.5 (weight/volume) soil: water suspensions in accordance with the procedure described by Thomas (1996). Organic carbon was determined by the wet digestion (oxidation) method of WalkleyBlack (Nelson and Sommers, 1996). Cation exchange capacity (CEC) was determined by the ammonium acetate $\left(\mathrm{CH}_{3} \mathrm{COONH}_{4}\right)$ saturation method (Sumner and Miller, 1996), while the leachates from the proceeding steps were used for determination of exchangeable $\mathrm{Ca}$ and $\mathrm{Mg}$ by atomic absorption spectrophotometer while $\mathrm{K}$ and $\mathrm{Na}$ were determined by flame photometer. Total nitrogen was determined by the Kjeldah method as described by Okalebo et al., (1993). Available phosphorus was determined by the Olsen method in accordance with the procedure described by Juo (1978). Particle size distribution was determined by the hydrometer method as described by Gee and Bauder (1986) and textural classes of the soils were determined by the United States Department of Agriculture procedure (USDA, 1975). $\mathrm{Zn}, \mathrm{Cu}, \mathrm{Mn}$ and $\mathrm{Fe}$ were extracted by DTPA and measured or quantified by atomic absorption spectrophotometer as described by Lindsay and Norvel (1978).

\section{Experimental design and planting}

Land preparation involved clearing, ploughing, layout and finally planting. The experimental design followed a randomized complete block design (RCBD) in a 3factorial arrangement with 4 replications per treatment. The experimental treatments consisted of 2 levels of Rhizobium inoculation (with and without Rhizobium), 2 legumes (legume 1 being $P$. Vulgaris and legume 2 being $D$. Lablab) and 5 intercropping systems (sole maize or sole legumes, 1 row maize to 1 row legumes (1:1) i.e. $0 \mathrm{~m}$ or $0.45 \mathrm{~m}$ of legume from maize row, 1 row maize to 2 rows of legumes (1:2) i.e. $0.1 \mathrm{~m}$ or $0.2 \mathrm{~m}$ of legumes from maize rows). The field plots measured $4 \mathrm{~m} \times 4 \mathrm{~m}$ with 5 rows of maize spaced at $(0.9 \mathrm{~m} \times 0.5 \mathrm{~m})$ apart and 8 rows of legumes spaced at $(0.5 \mathrm{~m} \times 0.2 \mathrm{~m})$. The plots were interspaced by $1 \mathrm{~m}$ to allow management of crops. The first season crops were planted on $5^{\text {th }}$ April, 2015 while the second season crops were planted on $14^{\text {th }}$, November, 2015. Prior to planting phosphate fertilizer as triple superphosphate was applied at the rates of $20 \mathrm{~kg}$ P/ha to supply soil P for crops uptake. The fertilizer was uniformly applied 
in to the holes and covered with little soil before planting maize or legume seeds to avoid seeds burning. The BIOFIX legume inoculants were obtained from MEA Company Nairobi-Kenya, sold under license from the University of Nairobi. Maize variety (SEEDCO 503) was obtained from SEEDCO Seed Company in Arusha and Common bean seeds variety (Lyamungo 90) and Dolichos lablab variety (Rongai) were obtained from Selian Agricultural Research Institute-Arusha-Tanzania. Before sowing, the legume seeds were thoroughly mixed with Rhizobium inoculants to supply (109cells/gseed), following procedures stipulated by products manufacturer. To avoid contamination, the non-inoculated seeds were planted first followed with the inoculated seeds. Three seeds were planted and thinned to two plants after full plant establishment. Interplant spacing was maintained at $0.5 \mathrm{~m}$ throughout for maize and $0.2 \mathrm{~m}$ for legumes. The plant density was kept constant on a total plot area basis set at the optimum for sole crops and kept the same in intercrops. The plant population density of maize and legumes were maintained at 44,000 and 200,000 plants per hectare respectively. Weeding and other agronomic practices were done manually using hand hoe at different growth stage of the crop plant.

\section{Data collection}

Data collected were plant samples, nodule number per plant, nodule fresh weight and nodule dry weight. Plant samples (maize, common bean and dolichos lablab) collection involved cutting above ground portion of ten plants which were randomly selected at flowering stage from each plot for the determination of shoot percentage nitrogen. Prior to analysis, the fresh plant samples were washed using distilled water and drip dried. Thereafter, the samples were oven dried at $70{ }^{\circ} \mathrm{C}$ to constant weights and ground to a fine powder $(0.5 \mathrm{~mm}$ sieve) for plant tissue analysis. Total plant nitrogen analysis was determined by Kjeldah method as described by Okalebo et al., (1993). Number of nodules per plant determination involved watering the soil before uprooting the plants and with an aid of a sharpened peg the plants were uprooted and carefully washed by soaking in a half filled bucket. The nodules were carefully detached from the roots and nodule numbers per plant and nodule weight per plant were determined as described by Peoples et al., (1989).

\section{Estimation of $\mathbf{N}$ fixation}

The technique used to estimate $\mathrm{N}$ fixation was the Total Nitrogen Difference (TND) method. This was done by comparing total nitrogen of the legume with that of a nonlegume (Murray et al., 2008). The amount of $\mathrm{N}$ fixed was calculated by subtracting total nitrogen of the reference crop (maize) from that of the legume (Common bean and Dolichos lablab), and the difference value is assumed as $\mathrm{N}$ derived by $\mathrm{BNF}\left(\mathrm{N}_{2}\right.$ fixed).

Thus, $\mathrm{N}_{2}$ fixed $=$ Total $\mathrm{N}$ in legume - Total $\mathrm{N}$ in reference crop

Where,

$\% \mathrm{Ndfa}=([$ Total $\mathrm{N}$ in legume - Total $\mathrm{N}$ in reference crop] / Total $\mathrm{N}$ in legume) $\times 100$

$\% \mathrm{Ndfa}$ is the percentage of $\mathrm{N}_{2}$ derived from the atmosphere

Total $\mathrm{N}_{2}$ fixed in plants $\left(\mathrm{kg} \mathrm{ha}^{-1}\right)=($ Dry matter weight $\left(\mathrm{kg} \mathrm{ha}^{-1}\right) \times \% \mathrm{~N}$ in plants $) / 100$

\section{Data analysis}

A 3-way ANOVA was used to analyze data collected. The analysis was done using 
STATISTICA software program 2010. Fisher's least significant difference was used to compare treatment means (Steel and Torrie, 1980).

\section{Results and Discussion}

\section{Changes of physical and chemical properties of the soils and their effect on BNF}

The soil textural class of the soils was clay loam (Table 1). It has been reported that soils with high clay loam contents are suitable for maize/ legumes production because of their moderate capacities to retain plant nutrients and soil water (De Datta, 1981). The high clay loam contents in these soils would further allow the moderate percolation of water through the soils, hence encouraging roots respiration and other biological processes in the soils including symbiotic BNF process.

The soils' $\mathrm{pH}$ values for the two seasons ranged from 6.45 to 6.80 in season 1 and 2, respectively (Slightly acidic to slightly neutral soil reaction) (Table 1). The optimum soil $\mathrm{pH}$ for maize/ legume plants is 6.5 to 7.0 (Landon, 1991). Brockwell et al., (1991) reported a $10^{-3}$ decrease in the number of soil bacteria in soils with a $\mathrm{pH}<6$ compared to those with a $\mathrm{pH}>7.0$. There is a range of effects of soil $\mathrm{pH}$ on rhizobia, but relatively few grow and survive well below $\mathrm{pH}$ values of 4.5 to 5.0. Although the microsymbiont appears more $\mathrm{pH}$ sensitive than the host partner (Maria de, 2007), acidity also influences both the growth of the legume plant and the infection process.

The percentage total nitrogen in the soils ranged from 0.09 to $0.35 \%$ for season 1 and 2 respectively (Table 1$)$. These values are categorised as low to high (Landon, 1991) hence the soils in season 1 were deficient in nitrogen but sufficient in season 2 for plant growth. Pillai (2005) reported that N requirement is categorized as low, medium and high when the percentage total nitrogen values are less than $0.1 \%, 0.1-0.2 \%$ and $>0.2 \%$, respectively. The low total nitrogen might have been caused by limited use of organic soil amendments, $\mathrm{N}$ uptake by plants, leaching and denitrification. The high nitrogen content in soils for season 2 was due to legumes nitrogen fixation and incorporation of first season crop residues in to the soil. High $\mathrm{N}$ in the soil inhibits legumes nodule formation and symbiotic nitrogen fixation (Sprent et al., 1988; Weria et al., 2013). However, total nitrogen in soils is not a good index of nitrogen availability as the $\mathrm{N}$ in soils occur in complex organic compounds that have to be biochemically transformed to $\mathrm{NH}_{4}{ }^{+}$and $\mathrm{NO}_{3}{ }^{-}$that can be taken up by plants.

The organic carbon contents in the soils were $2.42 \%$ to $3.99 \%$ (Table 1) for season 1 and 2 , respectively. These values are rated as low as they are less than $4 \%$ (Landon, 1991). The low percent organic carbon contents translate to low organic matter contents in the soils. Organic matter in soils influence both the physical, chemical and biological properties of soils, such as soil structure, water retention, nutrient contents and retention and micro-biological life and activities in the soils.

The Olsen extractable Phosphorus in the soils ranged from 13.91 to $19.30 \mathrm{mg} \mathrm{P} \mathrm{kg}^{-1}$ soil (Table 1) for season 1 and 2, respectively. The soils' extractable phosphorus values would be rated as high (Landon, 1991). There are marked differences in rhizobial and plant requirements for $\mathrm{P}$ with the slow - growing more tolerant to low $\mathrm{P}$ than the fast growing rhizobia (Weria et al., 2013). Nodules themselves are strong sinks for $\mathrm{P}$ and 
nodulation and $\mathrm{N}_{2}$ fixation are strongly influenced by $\mathrm{P}$ availability (Leung and Bottomley, 1987). Weria et al., (2013) indicated that when legumes-dependent on symbiotic nitrogen receive an inadequate supply of phosphorus, they may suffer nitrogen deficiency. The observed soil available phosphorus values would not satisfy the phosphate demand by biological nitrogen fixation; hence phosphate application to these soils as inorganic or organic fertilizers aim at raising the $\mathrm{P}$ availability status to the critical $P$ concentration range of $15-20 \mathrm{mg} \mathrm{P} \mathrm{kg}{ }^{-1}$ soil is important (Jones et al., 1982; PCARRD, 1978).

The cation exchange capacities (CEC) of the soils for the two seasons ranged from 19.68 to $25.95 \mathrm{Cmol}_{(+)} \mathrm{kg}^{-1}$ soil for season 1 and 2 , respectively (Table 1 ). These CEC values would be rated as medium, where 5-12.0 $\mathrm{Cmol}_{(+)} \mathrm{kg}^{-1}$ is rated as low, 12.1-25.0 $\mathrm{Cmol}_{(+)} \mathrm{kg}^{-1}$ as medium and 25-40 $\mathrm{Cmol}_{(+)}$ $\mathrm{kg}^{-1}$ as high (Landon, 1991). The medium CEC of the soils is attributed to the nature of the parent materials from which the soils were developed and the type of the layer or amorphous silicate clay minerals in the soils. The high CEC in season 2 was attributed by maize/ legume crop residues incorporated from season 1 harvest. These indicate the presence of sufficient soil cations for BNF process.

The exchangeable bases displaced by $\mathrm{NH}_{4}{ }^{+}$ through ion exchange process/ mechanism included calcium $\left(\mathrm{Ca}^{2+}\right)$, magnesium $\left(\mathrm{Mg}^{2+}\right)$, sodium $\left(\mathrm{Na}^{+}\right)$and potassium $\left(\mathrm{K}^{+}\right)$.

The exchangeable $\mathrm{Ca}$ levels in the two seasons (Table 1) are categorized as very high, that is $>2 \mathrm{Cmol} \mathrm{Ca} \mathrm{kg}^{-1}$ soil (Landon, 1991). A study by Weria et al., (2013) showed that legume plants under $\mathrm{N}_{2}$-fixing symbiosis, Ca deficiency decreased nitrogen fixation in nodules and also affects attachment of rhizobia to root hairs and nodulation. Therefore, the availability of $\mathrm{Ca}$ at the study area is not a soil fertility constraint to BNF process.

The exchangeable $\mathrm{Mg}$ in the soils (Table 1) are rated as high $\left(>0.5 \mathrm{Cmol}_{(+)} \mathrm{kg}^{-1}\right.$ soil $)$ according to Landon (1991). However, the availability of $\mathrm{Mg}$ of the soils might be reduced by the high $\mathrm{Ca}$ : $\mathrm{Mg}$ ratio greater than 5:1 due to antagonistic effects of calcium (Landon, 1991).

The exchangeable Na values (Table 1) are rated as very high (Landon, 1991). The legume-Rhizobium symbioses and nodule formation on legumes are more sensitive to salt or osmotic stress than are the rhizobia (Zahran, 1991). Salt stress inhibits the initial steps of Rhizobium-legume symbiosis. A study by Nair et al., (1993) showed little curling or deformation soybean root hairs when inoculated with Bradyrhizobium japonicum in the presence of $170 \mathrm{mM} \mathrm{NaCl}$, and nodulation was completely suppressed by $210 \mathrm{mM} \mathrm{NaCl}$. Legume is moderately tolerant to sodic soil conditions (ESP $=20-$ 40) hence the crops and BNF process would not be adversely affected by the high exchangeable Na values of the soils.

The exchangeable $\mathrm{K}$ in the soils (Table 1) is rated as high (>0.4 cmol K kg${ }^{-1}$ soil) according to Landon (1991). It has been reported that soils with large amounts of available $\mathrm{K}$ lose some of the $\mathrm{K}$ through fixation and those with low amounts have their exchangeable $\mathrm{K}$ increased through transformation of the non-available $\mathrm{K}$ to available/exchangeable forms under field conditions (Pillai, 2005). Weria et al., (2013) reported a qualitative requirement for $\mathrm{K}$ for some rhizobia which show restricted growth when $\mathrm{K}$ is deficient in the growth medium. Thus the soil $\mathrm{K}$ values (1.52 to 2 
$\mathrm{cmol}_{(+)} \mathrm{kg}^{-1}$ soil) are above the minimum levels of (0.07 and $0.2 \mathrm{cmol} \mathrm{K} \mathrm{kg}^{-1}$ soil) for $\mathrm{BNF}$ hence not deficient.

The DTPA extractable $\mathrm{Zn}, \mathrm{Cu}, \mathrm{Mn}$ and $\mathrm{Fe}$ in the soils ranged from 1.15 to $1.7,7.65$ to $8.55,127$ to 136.64 and 137 to $143.58 \mathrm{mg}$ $\mathrm{kg}^{-1}$ soil, for season 1 and 2 respectively as shown in Table 1 . These values are rated as high > $1.0 \mathrm{mg} \mathrm{Zn} \mathrm{kg}^{-1}$ soil, > $0.75 \mathrm{mg} \mathrm{Cu} \mathrm{kg}$ ${ }^{1}$ soil, > $1.5 \mathrm{mg} \mathrm{Mn} \mathrm{kg}{ }^{-1}$ soil and > $5 \mathrm{mg} \mathrm{Fe}$ $\mathrm{kg}^{-1}$ soil according to Landon (1991). Adverse effects of heavy metals on nodulation and $\mathrm{N}_{2}$ fixation of legumes have been reported for clover and chickpea (Rother et al., 1983; Yadav and Shukla, 1983). Giller et al., (1989) suggested two possibilities to explain the mechanism by which the elevated metal concentrations eliminated $\mathrm{N}_{2}$ fixation: (i) one or more of the metals present might have prevented the formation of $\mathrm{N}_{2}$-fixing nodules by effective Rhizobium strains present in the soil or (ii) the metal contamination might have resulted in elimination of the effective Rhizobium strains from the soil. Based on the soils analytical data, the soil fertility limitations with respect to maize/ legume production in SARI farm include low soil organic matter, low total nitrogen and medium soil phosphorus. These limitations can be corrected or addressed through application and incorporation of plant residuals in soils and maize/ legume intercrops.

Effect of Rhizobium inoculation and intercropping systems on number of nodules, nodules fresh weight, nodules dry weight and nitrogen fixation of two legumes

The study indicates that rhizobium inoculation significantly $\quad(\mathrm{P} \leq 0.001)$ increased number of nodules by 19.7 and $20.5 \%$, nodules fresh weight increased by 22.6 and $18.7 \%$, nodules dry weight increased by 19.1 and $27.3 \%$ while nitrogen fixation increased by 17.7 and $17.5 \%$ in season 1 and 2 respectively (table 2 ) for two legumes $(P$. vulgaris and $D$. lablab). The reason might be due to the synthetic inoculation of Rhizobium, which increased the number of bacteria and hence more nodules number, nodules weight and nitrogen fixation per plant (Muhammad, 2011). Further studies by Bambara (2009), Tairo and Ndakidemi (2013) showed that Rhizobium inoculation increased number of nodules in both glasshouse and field experiment. The results also revealed that few nodules were observed on uninocculated plots. This is an indicator of the presence of indigenous legumes nodulating bacteria in the experimental soil (Bekere and Hailemariam, 2012). Differences among the legumes in nodule numbers were probably an expression of the interaction between Rhizobium strain and host plant. Rennie and Kemp (1984) reported cultivar differences in inoculation caused by the presence of toxic substances in seed coats, or differences in root exudates. The inoculated plants had the highest nodule dry weight and amount of nitrogen which differed significantly from non-inoculated plots. This also indicates that there were native rhizobia in the soils where legumes were planted. Although symbiotic nitrogen fixing potential in common bean is considered to be low in comparison with dolichos lablab, the present study also showed increased in nitrogen associated with $\mathrm{N}$ fixation suggesting a prospect for improving nodulation by using inoculants. These differences also reflect the sensitivity of the bean-Rhizobium symbiosis to many environmental factors that can have either an enhancing or reducing effect on $\mathrm{N}$ fixation. Graham and Vance (2003) explained that numerous changes occur in host and bacterial gene expression during infection, nodule development, and function with 
approximately 100 host legume and rhizobial genes involved. A study by Chemining'wa et al., (2007) on effect of rhizobia inoculation and starter- $\mathrm{N}$ on nodulation and yield of grain legumes revealed that in most cases, common bean had significantly higher nodule numbers and nodule weight than most of the other legumes. Mukhtar and Nourai (1988) found that high doses of nitrogen reduced nodulation and nitrogenous activity and concluded that the starter doses of $10 \mathrm{~kg}$ $\mathrm{N} /$ ha improved plant stand and enhanced $\mathrm{N}_{2}$ fixation and production. Otieno et al., (2007) also reported similar results that rhizobial inoculation significantly increases nodule number and dry weight in studied legume species. When dolichos lablab plant is inoculated can fix up to $400 \mathrm{~kg} \mathrm{~N}^{-1} \mathrm{yr}^{-}$ 1 (Smith and Hume, 1987). Positive and significant correlations of nodule number were observed with nodule weight and nitrogen fixation in both seasons but on contrary, there was no significant correlation between nodules fresh weight and nodule dry weight.

Cropping systems were significant $(\mathrm{P} \leq 0.001)$ on number of nodules per plant with increase of 4.5 and $5.5 \%$, nodules fresh weight with increase of 12.1 and $9.7 \%$, nodules dry weight with increase of 12.2 and $12.5 \%$, nitrogen fixation with increase of 42.3 and $35.9 \%$ in season 1 and 2 (Table 2). The cropping system 1 (sole crop) had the highest nodules number per plant, nodules fresh and dry weight and nitrogen fixation in season 1 and 2. Regardless of inoculants used in cropping systems, the overall increases of the measured parameters were in cropping system 1. On the other hand cropping systems $2,3,4$ and 5 were close to each other (table 2).

Intercropping legumes with non-leguminous crops result in competition for light, water and nutrients that can affect number of nodules and $\mathrm{N}_{2}$ fixation negatively. A study by Moses et al., (2013) noted that some nodulated legumes are capable of fixing atmospheric $\mathrm{N}$ and therefore will reduce competition for $\mathrm{N}$ when cereals are included in an intercropping system. However, it has been shown that when mineral $\mathrm{N}$ is depleted in the root zone of the legume component by the non-leguminous intercrops, $\mathrm{N}$ fixation of legumes may be promoted (Ashish et al., 2015). Intercropping increase opportunities for N-use complimentarily, reducing the need for fertiliser- $\mathrm{N}$, either by increasing the availability of soil $\mathrm{N}$ or by $\mathrm{N}$ transfer (Chris van and Christopher, 2000). The present study indicated that, the total amount of $\mathrm{N}$ fixed per unit area in intercropped systems is often lower due to decreased legume population densities, and increased competition for light, water and nutrients by the non-legume. An increase in the total amount of $\mathrm{N}_{2}$ fixed could occur when the intercropped legume uses more effectively limited resources.

The interaction between Rhizobium inoculation and cropping systems was significant $(\mathrm{P} \leq 0.01)$ on nodules dry weights for season 1 and 2 respectively. These results are in line with the studies of Santalla et al. (2001) and Anshu (2014) that the nodulation and nitrogenase activity led to increased nodules dry weights of plants inoculated with Rhizobium. Dolichos lablab gave higher nodules weight in all cropping systems than common bean with cropping system 1 (sole crop) being dominant.

Intercropping maize and dolichos lablab or common bean with rhizobium inoculation enhanced the Biological Nitrogen Fixation (BNF) process which increased $\mathrm{N}$ fixation on average by more than $27 \mathrm{~kg} \mathrm{~N} \mathrm{ha}^{-1}$ with an improvement of soil nutrients from season 1 to season 2 . 
Int.J.Curr.Microbiol.App.Sci (2016) 5(10): 135-149

Table.1 Some of the chemical and physical properties of the composite soil samples from the research site

\begin{tabular}{|c|c|c|c|c|c|c|c|c|}
\hline \multirow{3}{*}{ Soil Parameters } & \multicolumn{4}{|c|}{ Season 1} & \multicolumn{4}{|c|}{ Season 2} \\
\hline & \multicolumn{2}{|c|}{ Soil samples } & \multirow[t]{2}{*}{ Mean } & \multirow[t]{2}{*}{ Rating $^{1}$} & \multicolumn{2}{|c|}{ Soil samples } & \multirow[t]{2}{*}{ Mean } & \multirow[t]{2}{*}{ Rating $^{\top}$} \\
\hline & 1 & 2 & & & 1 & 2 & & \\
\hline $\mathrm{pH}$ (water) & 6.40 & 6.50 & 6.45 & Slightly acidic & 6.70 & 6.90 & 6.80 & Slightly neutral \\
\hline $\mathrm{EC}(\mathrm{mS} / \mathrm{cm})$ & 0.16 & 0.16 & 0.16 & Normal & 0.18 & 0.19 & 0.19 & Normal \\
\hline Organic carbon $(\%)$ & 2.43 & 2.41 & 2.42 & Low & 3.86 & 4.12 & 3.99 & Medium \\
\hline Organic matter $(\%)$ & 4.23 & 4.19 & 4.21 & Low & 6.72 & 7.17 & 6.95 & Medium \\
\hline Total nitrogen $(\%)$ & 0.09 & 0.09 & 0.09 & Low & 0.28 & 0.41 & 0.35 & Medium \\
\hline Extractable $\mathrm{P}$ (Olsen, $\mathrm{mg} \mathrm{kg}^{-1}$ ) & 13.80 & 14.01 & 13.91 & Medium & 19.20 & 19.40 & 19.30 & High \\
\hline Exchangeable $\mathrm{Ca}\left(\mathrm{cmol} \mathrm{kg}^{-1}\right)$ & 5.60 & 5.50 & 5.55 & High & 5.90 & 6.20 & 6.05 & High \\
\hline Exchangeable $\mathrm{Mg}\left(\mathrm{cmol} \mathrm{kg}^{-1}\right)$ & 4.20 & 4.20 & 4.20 & High & 5.30 & 5.60 & 5.45 & High \\
\hline Exchangeable $\mathrm{Na}\left(\mathrm{cmol} \mathrm{kg}^{-1}\right)$ & 5.70 & 5.80 & 5.75 & High & 6.80 & 7.10 & 6.95 & High \\
\hline Exchangeable $\mathrm{K}\left(\mathrm{cmol} \mathrm{kg}{ }^{-1}\right)$ & 1.50 & 1.57 & 1.54 & High & 1.90 & 2.10 & 2.00 & High \\
\hline $\mathrm{CEC}\left(\mathrm{cmol} \mathrm{kg}^{-1}\right)$ & 19.60 & 19.75 & 19.68 & Medium & 24.70 & 27.20 & 25.95 & High \\
\hline Zinc $\left(\mathrm{mgkg}^{-1}\right)$ & 1.10 & 1.20 & 1.15 & High & 1.60 & 1.80 & 1.70 & High \\
\hline Copper $\left(\mathrm{mgkg}^{-1}\right)$ & 7.50 & 7.80 & 7.65 & High & 8.40 & 8.70 & 8.55 & High \\
\hline Manganese $\left(\mathrm{mgkg}^{-1}\right)$ & 128.00 & 126.00 & 127.00 & High & 133.08 & 140.20 & 136.64 & High \\
\hline Iron $\left(\mathrm{mgkg}^{-1}\right)$ & 137.00 & 137.00 & 137.00 & High & 141.10 & 146.30 & 143.58 & High \\
\hline \multicolumn{9}{|l|}{ Particle size distribution } \\
\hline Sand $(\%)$ & 40.00 & 40.00 & 40.00 & & 39.00 & 39.50 & 39.25 & \\
\hline Silt (\%) & 28.00 & 28.00 & 28.00 & & 28.00 & 28.00 & 28.00 & \\
\hline Clay (\%) & 32.00 & 32.00 & 32.00 & & 33.00 & 32.50 & 32.75 & \\
\hline Textural class & $\mathrm{CL}$ & $\mathrm{CL}$ & $\mathrm{CL}$ & & $\mathrm{CL}$ & $\mathrm{CL}$ & $\mathrm{CL}$ & \\
\hline
\end{tabular}

Note: CL= Clay loam

Soil parameters rating was done according to Landon (1991). 
Table.2 Effects of Rhizobium inoculation legumes and cropping systems on number of nodules, nodules fresh weight, nodules dry weight and nitrogen fixation of two legumes (P. vulgaris L. and Lablab purpereus L.)

\begin{tabular}{|c|c|c|c|c|c|c|c|c|}
\hline \multirow[b]{2}{*}{ Treatments } & \multicolumn{4}{|c|}{ Season 1} & \multicolumn{3}{|c|}{ Season 2} & \multirow[b]{2}{*}{$\begin{array}{l}\mathrm{N} \text { fixation } \\
\text { (kg/ha) }\end{array}$} \\
\hline & $\begin{array}{l}\text { No of } \\
\text { nodules }\end{array}$ & $\begin{array}{l}\text { Nodule fresh } \\
\text { weight (gm) }\end{array}$ & $\begin{array}{l}\text { Nodule dry } \\
\text { weight (gm) }\end{array}$ & $\begin{array}{l}\mathrm{N} \text { fixation } \\
\text { (kg/ha) }\end{array}$ & $\begin{array}{l}\text { No of } \\
\text { nodules }\end{array}$ & $\begin{array}{l}\text { Nodule fresh } \\
\text { weight (gm) }\end{array}$ & $\begin{array}{l}\text { Nodule dry } \\
\text { weight (gm) }\end{array}$ & \\
\hline \multicolumn{9}{|l|}{ Rhizobium } \\
\hline $\mathrm{R}-$ & $15.50 \pm 0.21 b$ & $0.93 \pm 0.02 b$ & $0.47 \pm 0.01 \mathrm{~b}$ & $65.54 \pm 2.83 b$ & $14.85 \pm 0.15 b$ & $1.07 \pm 0.02 b$ & $0.44 \pm 0.01 \mathrm{~b}$ & $78.60 \pm 3.06 b$ \\
\hline $\begin{array}{l}\text { R+ } \\
\text { Legumes }\end{array}$ & $18.55 \pm 0.27 \mathrm{a}$ & $1.14 \pm 0.03 \mathrm{a}$ & $0.56 \pm 0.01 \mathrm{a}$ & $77.17 \pm 2.90 \mathrm{a}$ & $17.90 \pm 0.15 \mathrm{a}$ & $1.27 \pm 0.03 \mathrm{a}$ & $0.56 \pm 0.01 \mathrm{a}$ & $92.35 \pm 3.72 \mathrm{a}$ \\
\hline 1 & $17.55 \pm 0.39 \mathrm{a}$ & $0.91 \pm 0.02 b$ & $0.45 \pm 0.01 b$ & $57.32 \pm 2.00 \mathrm{~b}$ & $16.50 \pm 0.31 \mathrm{a}$ & $1.04 \pm 0.02 b$ & $0.43 \pm 0.01 \mathrm{~b}$ & $68.09 \pm 1.97 b$ \\
\hline 2 & $16.50 \pm 0.26 b$ & $1.16 \pm 0.02 \mathrm{a}$ & $0.58 \pm 0.01 \mathrm{a}$ & $85.39 \pm 2.02 \mathrm{a}$ & $15.77 \pm 0.24 b$ & $1.29 \pm 0.02 \mathrm{a}$ & $0.57 \pm 0.01 \mathrm{a}$ & $102.85 \pm 2.49 a$ \\
\hline \multicolumn{9}{|c|}{ Cropping systems } \\
\hline 1 & $17.25 \pm 0.43 \mathrm{a}$ & $1.11 \pm 0.06 \mathrm{a}$ & $0.55 \pm 0.03 \mathrm{a}$ & $90.08 \pm 4.36 \mathrm{a}$ & $16.94 \pm 0.43 \mathrm{a}$ & $1.24 \pm 0.06 \mathrm{a}$ & $0.54 \pm 0.03 \mathrm{a}$ & $104.95 \pm 5.78 \mathrm{a}$ \\
\hline 2 & $17.50 \pm 0.76 \mathrm{a}$ & $0.99 \pm 0.04 c$ & $0.49 \pm 0.02 \mathrm{c}$ & $69.84 \pm 4.69 b$ & $16.50 \pm 0.43 b$ & $1.13 \pm 0.04 \mathrm{~cd}$ & $0.49 \pm 0.03 b$ & $84.20 \pm 5.31 b$ \\
\hline 3 & $16.81 \pm 0.49 \mathrm{a}$ & $1.02 \pm 0.04 \mathrm{bc}$ & $0.50 \pm 0.02 b c$ & $67.36 \pm 3.88 \mathrm{ab}$ & $16.31 \pm 0.45 b$ & $1.16 \pm 0.04 b c$ & $0.49 \pm 0.02 b$ & $80.96 \pm 4.79 a b$ \\
\hline 4 & $16.81 \pm 0.48 \mathrm{a}$ & $1.04 \pm 0.05 b$ & $0.51 \pm 0.02 b$ & $66.21 \pm 3.99 \mathrm{ab}$ & $16.06 \pm 0.48 b c$ & $1.17 \pm 0.05 b$ & $0.48 \pm 0.02 b$ & $80.05 \pm 4.92 \mathrm{ab}$ \\
\hline 5 & $16.75 \pm 0.53 \mathrm{a}$ & $1.00 \pm 0.04 \mathrm{c}$ & $0.50 \pm 0.02 b c$ & $63.29 \pm 3.93 c$ & $16.06 \pm 0.47 b c$ & $1.13 \pm 0.04 \mathrm{~d}$ & $0.48 \pm 0.02 b$ & $77.20 \pm 4.91 \mathrm{c}$ \\
\hline \multicolumn{9}{|c|}{ 3-Way ANOVA (F-statistic) } \\
\hline Rhiz & $80.02 * * *$ & $465.05 * * *$ & $196.00 * * *$ & $81.57 * * *$ & $262.66 * * *$ & $366.11 * * *$ & $343.19 * * *$ & $66.44 * * *$ \\
\hline Leg & $9.48 * *$ & $699.59 * * *$ & $396.93 * * *$ & $475.42 * * *$ & $22.87 * * *$ & $614.40 * * *$ & $464.82 * * *$ & $424.88 * * *$ \\
\hline Cr syst & $0.76 \mathrm{~ns}$ & $19.11 * * *$ & $11.11 * * *$ & $55.51 * * *$ & $3.00 *$ & $16.01 * * *$ & $13.51 * * *$ & $35.13 * * *$ \\
\hline
\end{tabular}

-R: Without Rhizobium, +R; With Rhizoubium, Legume 1: Common bean; Legume 2: D. Lablab; Cropping System 1, 2, 3, 4 and 5 are sole maize, $10 \mathrm{~cm}, 20 \mathrm{~cm}, 45 \mathrm{~cm}$ and $0 \mathrm{~cm}$ of legumes from maize row respectively; Rhiz; Rhizobium, Leg; Legume, Cr Syst; Cropping Systems. Values presented are means $\pm \mathrm{SE}, \mathrm{n}=4$. *; **; *** = significant at $\mathrm{P} \leq 0.05, \mathrm{P} \leq 0.01, \mathrm{P} \leq 0.001$ respectively, $\mathrm{ns}=$ not significant, $\mathrm{SE}=$ standard error. Means followed by dissimilar letter in a column are significantly different from each other at $\mathrm{P}=0.05$ according to Fischer least significance difference (LSD 
Fig.1 Interactive effects of Rhizobium and cropping systems on nodules dry weights for season 1 and 2 (R-: Without Rhizobium, R+: With Rhizobium, CP1: Cropping system 1, CP2: Cropping system 2, CP3: Cropping system 3, CP4: Cropping system 4, CP5: Cropping system 5)

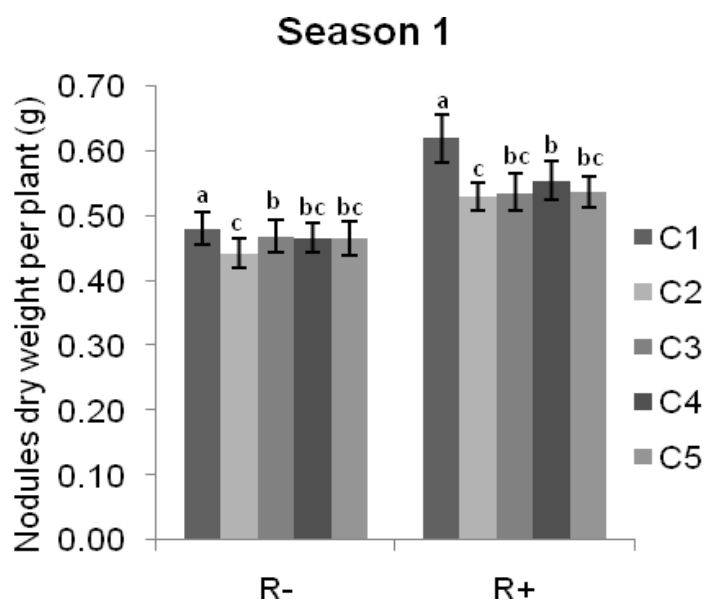

Therefore, it can be concluded from the results that the Rhizobium inoculation has positive impact on nodulation, nodules weights and nitrogen fixation. Increased cultivation of legumes intercropping is essential for the regeneration of nutrientdeficient soils and providing needed nutrients to humans and animals. In order to realize sustainable agriculture that is not dependent on mineral $\mathrm{N}$ fertilizer, studies on legume-rhizobia symbiosis is highly required that will contribute efficient crop legume production which leads to decrease production costs. Rhizobial inoculants have to be frequently applied/ used as biofertilizers because of its antagonistic effect on soil nutrients restoration. However there may be situations where $\mathrm{N}$ has to be applied, such as to cereal/ legumes intercrops, small quantity has to be applied as a starter dose of which may not affect nitrogen fixation of the legume crop.

\section{References}

Ahmed, A.E., Adlan, M.A.M., Hukhtar, N.O. 2005. Effect of plant growth promoting bacterium (Azospirillum brasilense) and Bradyrhizobium on

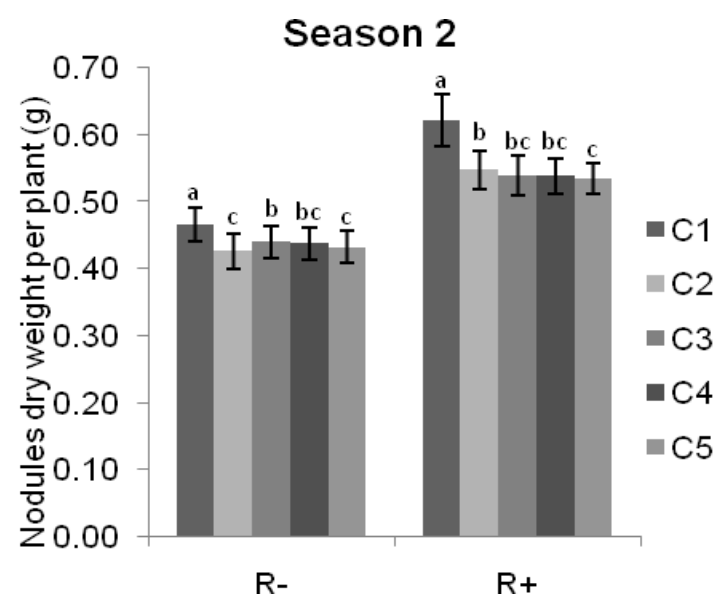

growth, yield and nitrogen fixation of groundnut (Arachis hypogaea L.). Gezira. J. Agric. Sci., 3: 137-147.

Anshu, S.C., Gupta, R.P. 2014. Interaction between Rhizobium leguminosarum strains and different varieties of pea. Int. J. Curr. Microbiol. Appl. Sci., 3(12): 674-681

Ashish, D., Ista, D., Vineet, K., Rajveer, S.Y., Mohit, Y., Dileep, G., Adesh, S., Tomar, S.S. 2015. Potential Role of Maize-Legume Intercropping Systems to Improve Soil Fertility Status under Smallholder Farming Systems for Sustainable Agriculture in India. Int. J. life Sci. Biotechnol. Pharma Res., 4: 3

Bambara, S.K. 2009. Effect of Rhizobium inoculation, molybdenum and lime on the growth and $\mathrm{N}_{2}$ fixation in P.vulgaris L. Thesis submitted in fulfilment of the requirements for the Masters Degree in Horticultural Science Cape Peninsula University of Technology pp 105.

Bekere, W., Hailemariam, A. 2012. Influences of Inoculation Methods and Phosphorus levels on Nitrogen Fixation Attributes and Yield of Soybean (Glycine max L.). At Haru, 
Western Ethiopia. Amer. J. Plant Nutr. Fertil. Tech., 2(2): 45-55.

Brockwell, J., Pilka, A., Holliday, R.A. 1991. Soil pH is a major determinant of the numbers of naturally-occurring Rhizobium meliloti in non-cultivated soils of New South Wales. Aust. J. Exp. Agric., 31: 211-219.

Carling, D.E., Riehle, W.G., Brown, M.F., Johnson, D.R. 1978. Effects of a vesicular-arbuscular mycorrhiza] fungus on nitrate reductase and nitrogenase activities in nodulating and non-nodulating soybeans. Phytopathol., 68: 1590-1596.

Chemining'wa, G.N., Muthomi, J.W., Theuri, S.W.M. 2007. Effect of rhizobia inoculation and starter $\mathrm{N}$ on nodulation, shoot biomass and yield of grain legumes. Asian J. Plant. Sci., 6: 1113-1118.

Chris van, K., Christopher, H. 2000. Agricultural management of grain legumes: has it led to an increase in nitrogen fixation? Field Crops Res., 65: 165-181.

CIAT-TSBF working group on BNF. 2004. Biological nitrogen fixation: A key input for integrated soil fertility management in the tropics, In: Serraj Red, Ed, Vol. Science Publishers, Enfield. pp 113-143.

De Datta, S.K. 1981. Principles and Practices of Rice Production. John Wiley and Sons, New York. 618pp.

Gadalla, A.E., Migdam, E.A., Awad, G.O., Somaya, S.M., Belgees, S.A. 2010. Potential Production and Application of Biofertilizers in Sudan. Pak. $J$. Nutr., 9(9): 926-934.

Gee, G.W., Bauder, J.W. 1986. Particle size analysis. In: Methods of Soil Analysis Part 1: Physical and Mineralogical Properties. Agronomy Series No 9. USA. pp. 383 - 409.

Gibson, K.G., Nkanata, M.G., Hamadi, B.,
Richard, C.C., John, M.M. 2013. Variation in Nitrogen Fixation among Three Bush Bean Cultivars Grown in Kenya when Inoculated with Three Rhizobia Strains. Greener. J. Agric. Sci., 3(11): 748-754.

Giller, K.E., McGrath, S.P., Hirsch, P.R. 1989. Absence of nitrogen fixation in clover grown on soil subject to longterm contamination with heavy metals is due to survival of only ineffective Rhizobium. Soil Biol. Biochem., 21: 841-848.

Graham, P.H., Vance, C.P. 2003. Legumes: Importance and constraints to greater use. Plant Physiol., 131: 872-877.

Jama, B.A., Nair, P.K.R. 2000. Decomposition and nitrogenmineralization pattern of Leucaena leucocephala and Cassia siamea mulch under tropical semiarid conditions in Kenya. Plant and Soil, 179: 275-285.

Jones, U.S., Katyal, J.C., Mammaril, C.P., Park, C.S. 1982. Wetland nutrient deficiency other than nitrogen. In: Rice research strategies for future. International Rice Research Institute, Los Banos, pp. 327-378.

Juo, A.S.R. 1979. Selected Methods for Soil and Plant Analysis. Manual Series No.1, International Institute for Tropical Agriculture, Ibadan, Nigeria. pp 70.

Kabahuma, M.K. 2013. "Enhancing biological nitrogen fixation in common bean (Phaseolus vulgaris L)" (2013). Graduate Theses and Dissertations. Paper 13162.

Kong, W.D., Zhu, Y.G., Fu, B.J., Han, X.Z., Zhang, L., He, J.Z. 2008. Effect of long-term application of chemical fertilizers on microbial biomass and functional diversity of a black soil. Pedosphere., 18(6): 801-808.

Landon, J.R. 1991. Booker tropical soil manual. A handbook of soil survey and agricultural land evaluation in the 
tropical and subtropical. Longman. 474pp.

Leung, K., Bottomley, P.J. 1987. Influence of phosphate on the growth and nodulation characteristics of Rhizobium trifolii. Appl. Environ. Microbiol., 53: 2098-2105.

Lindasy, W.L., Norvel, W.A. 1978.Development of DTPA Soil Test for Zinc, Iron, Manganese and Copper. J. Soil Sci. Soc. Am., 42: 421-428.

Lodwig, E.M., Hosie, A.H.F., Bourdès, A., Findlay, K., Allaway, D., Karunakaran, R., Downie, J.A., Poole, P.S. 2003. Amino-acid cycling drives nitrogen fixation in the legumeRhizobium symbiosis. Nature, 422: 722-726.

Maria de, F.L., Glaciela, K., Odair, A., Mariangela, H. 2007. Soybean [Glycine $\max (\mathrm{L}$.$) Merrill] rhizobial$ diversity in Brazilian oxisols under various soil, cropping, and inoculation managements. Biol. Fertil. Soils, 43: 665-674.

Ministry of Agriculture, Food Security and Cooperatives (MAFC). 2013. National Agricultural Policy. 51pp.

Moses, O.E., Godwin, A.A., Michael, I. 2013. Nodulation, Nitrogen Yield and Fixation by Bambara Groundnut (Vigna Subterranea (L.)Verdc.). Landraces Intercropped with Cowpea and Maize in Southern Guinea Savanna of Nigeria. Agric. Sci., 4: 1528.

Mugwe, J., Mugendi, D., Mucheru-Muna, M., Merckx, R., hianu, J., Vanlauwe, B. 2009. Determinants of the decision to adopt integrated soil fertility management practice by smallholder farmers in the central highlands of Kenya. Expl. Agric., 45: 61-75.

Muhammad, S.A., Abdur, R., Fazal, W., Syednoor, M.S.H., Ibadullah, J., Muhammad, A.K., Said, A.H.,
Muhammad, A.K., Zafar, I. 2011. Influence of Rhizobium inoculation on growth and yield of cultivars. Sarhad J. Agric., 26: 4.

Mukhtar, N.O., Babiker, H.M. 1994 Nitrogen fixation research in Sudan. An overview: Albuhuth. J., 4(1): 85101.

Murray, U., David, H., Mark, P., George, C., Bob, B., Ken, G., Bruno, A., Philip, C. 2008. Measuring plant associated nitrogen fixation in agricultural systems. Australian Hathazari, Chittagong. J. Soil Nature, 2: 25-30.

Myers, A. 1988. "Cereal cropping," Plant and Soil, vol. 174, pp. 30-33.

Nair， S., Jha， P.K., Babu， C.R. 1993. Induced salt tolerant rhizobia, from extremely salt tolerant Rhizobium gene pools, from reduced but effective symbiosis under non-saline growth. Microbios., 74: 39-51.

Nelson, D.W., Sommers, L.E. 1982. Organic carbon in soils. In: Methods of Soil Analysis. Part 2 Agronomy Monograph No.9 (Edited by Page, A. L.; Miller, R. H.; and Keeney, D. R.) American Society of Agronomy. Madison Wisc. pp 570-571.

Okalebo, J.R., Gathua, K.W., Woomer, P.L. 1993. Laboratory methods of soil analysis. A working Manual KARI, Nairobi, Kenya.

Otieno, P.E., Muthomi, J.W., Chemining'wa, G.N., Nderitu, J.H. 2007. Effect of rhizobia inoculation, farmyard manure and nitrogen fertilizer on growth, nodulation and yield of selected food grain legumes. Afr. Crop Sci. Soc., 8: 305-312.

Peoples, M.B., Brockwell, J., Herridge, D.F., Rochester, I.J., Alves, B.1.R., Urquiaga, S., Boddey, R.M., Dakora, F.D., Bhattarai, S., Maskey, S.L., Sampet, C., Rerkasem, B., Khans, D.F., Hauggaard-Nielsen, H., Jensen, 
B.S. 2009. The contributions of nitrogen-fixing crop legumes to the productivity of agricultural systems. Symbios., 48: 1-17.

Peoples, M.B., Faizah, A.W., Rerkasem, B., Herridge, D.F. 1989. Methods for evaluating nitrogen fixation by nodulated legumes in the field. Australian Centre for International Agricultural Research Canberra (ACIAR) Monograph No. 11, vii + 76 p.

Philippine Council for Agricultural Resource Research and Development (PCARRD). 1978. The Philippine Recommendation for Soil Fertility Management. Los Banos, Phillippine. $105 \mathrm{pp}$.

Pillai, K.G. 2005. Rice (Oryza sativa L.). World fertilizer use manual. Cereal crop Data. In: [www.fertilizer.org/ifa/bublicat/html/p ubman/rice.htm.]. Site visited on 18 June, 2016.

Postgate, J. 1998. Nitrogen Fixation, 3rd Edition. Cambridge University Press, Cambridg [http://en.wikipedia.org/wiki/Root_no dule]. Site visited on 18 June, 2016.

Rahman, M.M., Sofian-Azirun, M., Boyce, A.N. 2013. Response of nitrogen fertilizer and legumes residues on biomass production and utilization in rice-legumes rotation. J. Anim. Plant Sci., 23(2): 589-595.

Rennie, R.J., Kemp, G.A. 1984. SNdetermined time course for $\mathrm{N} 2$ fixation in two cultivars of field ean. Agron. J., 76: $146-154$.

Rother, J.A., Millbank, J.W., Thornton, I. 1983. Nitrogen fixation by white clover (Trifolium repens) in grasslands on soils contaminated with cadmium, lead and zinc. J. Soil. Sci., 34: 127136.

Santalla, M., Amurrio, J.M., de Ron, A.M.
2001. Symbiotic interaction between Rhizobium leguminosarum strains and Elite cultivars of Pisum Sativa L. J. Agon. Crop Sci., 187(1): 59-68

Smith, D.L., Hume, D.J. 1987. Comparison of 1: tSsay methods for N2 fixation utilizing white bean and soybean. Can. J. Plant Sci., 67: 11-19.

Sonoboir, H.L., Sarawgi, S.K. 2000. Nutrient uptake, growth and yield of chickpea as influenced by phosphorus, Rhizobium and phosphate solubilizing bacteria. Madras Agric. J., 87: 149151.

Sprent, J.I., Stephens, J.H., Rupela, O.P. 1988. Environmental effects on nitrogen fixation. In World Crops: Cool Season Food Legumes. Ed. R J Sumerfield. pp 801-810. Kluwer Academic Publishers, Dordrecht, The Netherlands.

Steel, R.G.D., Torrie, J.H. 1980. Principles and procedures of statistics: A biometrical approach, Second Edition. McGraw Hill, New York.

Streeter, J.G. 1988. Inhibition of legume nodule formation and N2 fixation by nitrate. CRC. Crit. Rev. Plant Sci., 7: $1-23$.

Sumner, M.E., Miller, W.P. 1996. Cation exchange capacity. In: Methods of soil analysis Part 3. Chemical Methods, SSSA Book Series, No.5: pp.12011229.

Tairo, E.V., Ndakidemi, P.A. 2013. Bradyrhizobium japonicum Inoculation and phosphorus supplementation on growth and chlorophyll accumulation in soybean (Glycine $\max$ L.). Am. J. Plant Sci., 4: 2281.

Temprano-Vera, F.J., Santamaría-Linaza, C., Daza-Ortega, A., Leidi, E.O., Rodríguez-Navarro, D.N. 1997. Tolerancia simbiótica a nitrato de distintas leguminosas. In: Sarmiento 
R, Leidi EO, Troncoso A, eds. Nutrición Mineral de las Plantas en la Agricultura Sostenible. Sevilla, Spain: Consejería de Agricultura y Pesca, Junta de Andalucía, pp. 41-47.

Thomas, G.W. 1996. Exchangeable cations. In: Methods of Soil Analysis. ASA Monograph No.9. pp.149-157.

United State Development of Agriculture (USDA) Soil Taxonomy. 1975. A basic system of soil classification for making and interpreting soil surveys. Soil survey Staff, Soil Conservation Service, Washington, D.C. 754pp.

Weria, W., Yaghoub, R., Kaveh, H.A. 2013. Role of Some of Mineral Nutrients in Biological Nitrogen Fixation. Bull.
Env. Pharmacol. Life Sci., 2(4): 77-84. Yadav, O.P., Shukla, U.C. 1983. Effect of zinc on nodulation and nitrogen fixation in chickpea (Cicer arietinum L.). J. Agric. Sci., 101: 559-563.

Zablotowicz, R.M., Reddy, K.N., Krutz, L.J., Gordon, R.E., Jackson, R.E., Price, L.D. 2011. Can Leguminous Cover Crops Partially Replace Nitrogen Fertilization in Mississippi Delta Cotton Production? Intl. J. Agron., 3: 1-9.

Zahran, H.H. 1991. Conditions for successful Rhizobium-legume symbiosis in saline environments. Biol. Fertil. Soils., 12: 73-80.

\section{How to cite this article:}

Prosper I. Massawe, Kelvin M. Mtei, Linus K. Munishi and Patrick A. Ndakidemi. 2016. Effect of Rhizobium and Intercropping Systems on Soil Nutrients and Biological Nitrogen Fixation as Influenced by Legumes (Phaseolus vulgaris and Dolichos lablab). Int.J.Curr.Microbiol.App.Sci. 5(10): 135-149. doi: http://dx.doi.org/10.20546/ijcmas.2016.510.016 